\title{
Educating young people to patriotism in the epic "Forty Girls"
}

\author{
A. T. Saparov ${ }^{1}$ \\ ${ }^{1}$ Nukus State Pedagogical Institute, Assistant Lecturer, \\ Department of Pre-School Education and Defectology
}

\begin{abstract}
People are born and raised from an early age and watch the nature of the place where they work. He learns language and customs. He also learns the words mother, father, country, homeland in his native language for the first time and communicates with each other. They are committed to self-sacrifice in their homeland. He amasses wealth for his country and people, creates wealth, protect his homeland from external enemies.
\end{abstract}

Keywords: patriotic feelings, motherland, generation.

\section{Introduction}

They see the wealth of our ancestors and contribute to it as a patriot of their homeland. A person who is a patriot of his homeland, as a child of the people, cultivates the region, the place of his birth, serves the land, try to spend his whole life here. Thus, the patriotic feelings formed during the captivity are passed on from generation to generation and develop. A person who respects his motherland calls him "my motherland", "my motherland".

Our people say, "A homeless man is a nightingale in a cage." These "love for the motherland, the native land, patriotic feelings" are the great force that creates and studies the history of the people, creates material and cultural riches with their strength and intelligence. We believe that the wealth of our country, the things that are in it, are the result of the work of the people. ${ }^{1}$

\section{Main part}

The people named the land and water, the city in honor of the heroes who became patriots of the country, built monuments. They were true patriots of that time, who cared about the people and defended their honor. These monuments were proudly narrated in the language of the people. Their exemplary deeds have been passed down from generation to generation. Such patriotic traditions and feelings are preserved in the patriots of the Karakalpak people, as in all nations. He sacrificed his people and country. All this is well known to us from legends, myths and legends, and folk tales.

Pupils and youth groups play an important role in educating young people in the spirit of patriotism and patriotism. To do this, we need to educate students to respect the path of our ancestors, to master the secrets of knowledge, to be politically mature, physically fit and fit. We need to educate students to love their country, to respect the property of the people, to be loyal to the victories of impartiality, to work for peace, to educate young people in all aspects, to educate young people in every way. ${ }^{2}$

Such patriotic feelings can be seen in the epic "Forty Girls", which is the priceless treasure of our people, the pride of our people.

"Forty Girls" also sings with a special eloquence, which, unlike the Karakalpak epics, has a special place in the defense of the Fatherland, patriotism. When Gulaim's father called him from Miyuvali to give him to the Jury, Gulaim said:

When my grandfather left,

When building a bronze fortress,

Without returning to the package,

When he gathered forty girls,

Khan of Kalmykia Surtaysha,

I am amazed,

I'm covered in blood,

During the day and night,

Orphan's blood,

When water flows,

The white wrist twisted,

Dressed in a white suit,

Irrevocable hero forty girls,

Follow the cover,

\footnotetext{
${ }^{1}$ Pirniyazova Natalya Vasilievna, Bekimbetova Aynagul Amangeldievna, Khojaniyazova Inkar Jumanazarovna-TUTOR'S SUPPORT OF FUTURE TEACHERS. European Journal of Research and Reflection in Educational Sciences Vol. 8 No. 3, 2020 Part II ISSN 2056-5852

${ }^{2}$ Бекимбетова Айнагул Амангельдиевна-ПРОФЕССИОНАЛЬНОЕ САМОСОВЕРШЕНСТВОВАНИЯ ПЕДАГОГОВ В ОБРАЗОВАТЕЛЬНОМ ПРОСТРАНСТВЕ. Теория и практика современной науки №9(51), сентябрь, 2019
} 
Climbing high mountains,

On the surface of the tube,

Let the flames burn,

When the ship arrives,

Crossing the sea,

Without knocking down a white poplar,

Without making any noise,

Without weeping the people of Sarkop,

He was called a hero.

Gulaim's words above are full of the highest feelings of a hero who loves the people and is devoted to serving them. Serving the people is the main goal of the national heroes in the epic. Gulaim says about his brothers who died cowardly:

Yes fathers, fathers,

His soul did not like fire,

When the time comes,

Helleny did not beat the group,

When the Day of Judgment comes,

The country was not fed by the enemy,

Not a relative.

That leads to. "Those who did not resist the enemy, it is better to die than to destroy the enemy's horde. ${ }^{3}$

The idea of the saga from beginning to end is full of feelings of high moral patriotism, unconditional love for the motherland and its people. This makes the epos immortal and close to the people, which the people have kept in their memory and loved during the captivity. The fact that the epic "Forty Girls" is full of patriotic ideas, in the epic, the public interest comes first, and all the actions of the protagonists are directed to the benefit of society. When Gulaim builds a fortress, trains his daughters in the mountains, and meets Aryslan, Surtaysha remembers the foreign invaders. The well-known heroes of the saga are depicted as fighters for freedom, not to mention the personal lives of Otbaskan and Sarbinaz.

"Forty Girls" is a story of skillful singing of the heroic struggle of the people against injustice, which has a strong social significance. The image of his heroes deeply depicts the wisdom, wisdom, strength, desires, dreams and greatness of the people. Gulaim's preparation for battle with the brave girls frightens his enemies. Surtaysha Gulaim destroys the people of Sarkop in his absence. The real reason for the destruction of Sarkop's people was not only the fact that the people's heroes did not take part in the war at that time, but also the inability of the people to unite and unite. For example, when the guerrillas stayed in Sarkop, Gulaim came and gave the following answer:

Heroes of the Sarcope,

He is not a hero,

The wise,

$\mathrm{He}$ is not wise.

What can I say,

He did not ride a horse,

Nine-layer tank,

He did not wear it over his shoulder,

Some candles,

Rubbing his wrists,

He did not hang up his sign,

The residue that came to cover,

Without entering the city,

He did not see a cure,

Without such a smell,

The lungs are compressed,

When the enemy's voice is heard,

The so-called heroes,

He fainted, fell down,

Stay tuned with ozie

Be head over heels,

Frightened, he stuck to the gorge,

He would do such things to me,

After Corgen, Surtaysha,

He was born in the city,

\footnotetext{
${ }^{3}$ The Way of Science International scientific journal № 4 (74), 2020 Founder and publisher: Publishing House «Scientific survey» The journal is founded in 2014 (March)
} 
He besieged me day and night,

Into the wilderness.

The words of the above-mentioned old men are distinguished by their deep meaning, the reasons for such a defeat are given with concrete examples, as well as the remedies of the seven victories. ${ }^{4}$

While training brave girls for military service in the mountains, Gulaim noticed that Sartaysha had been found in Sarkop. He rode with the girls to Sarkop. The grief of the heroes of the saga, on the one hand, shows the zeal for the life of the corrupt people, and on the other hand, the selfless struggle in the struggle against the enemy. Inspiring them:

Let's find out what happened to the snakes,

Let's make a strong mark,

Let's go, friends, in the hands of Surtaysha,

Let's fight against the people

he called to Gures. The patriotic feelings of the heroes were deeply felt in the epic "Forty Girls", especially in the fierce battles. Along with other heroes of the saga, Sarkop's hero Otbaskan's patriotism was especially felt in the struggle against Surtaysha. He was asleep in the city, unaware of the enemy's arrival. When the hero woke up and went into battle, his enemies could not stand his great force.

March hero like a family,

Driven out of the sarcophagus,

What a humiliating corset,

Khan of Kalmykia Surtaysha,

No matter what the suffering,

It did not burn,

March is Caesar's,

He did not love greed,

The head of Ketse,

Fear and trembling enemies,

He begged and did not bow his head.

When heroes fight with enemies, spearhead, shoot, and move away, the goal is to be ready to sacrifice their lives in the service of the people.

\section{Conclusion}

The Forty Maidens is also an example of the struggle for freedom and impartiality, in which the protection of the people from the enemy is deliberately set by his brave sons and daughters, who wage a fierce struggle against the conquering kings. Throughout its history, the Karakalpaks, who have experienced a bit of shock and aggression, have long dreamed of freedom and impartiality, and this dream of the people is very clearly reflected in his epic. A good example of this is the fact that the war against Surtaysha and Nadirsha ended in a genocide in accordance with the wishes of the people.

The conscious struggle for freedom and impartiality in the epic "Forty Maidens", the active participation of the people in this struggle with the mass heroes and the end of the struggle for freedom, showed that the authors of the epic had a deep understanding of people's lives and social thinking. This idea formed the basis of the content of the saga and became a characteristic feature of its value.

\section{References}

1. K. Masketov. Karakalpak heroic epic "Forty girls". Knox. 1962.

2. Karakalpak folklore.VI vol. Nukus. 1980 year. Educational and upbringing exercises. (Collection of scientific articles) Knox 2003

3. Abstracts of the conference. September 10-12, 1997. Karakalpakstan Publishing House, 1997

4. Pirniyazova Natalya Vasilievna, Bekimbetova Aynagul Amangeldievna, Khojaniyazova Inkar Jumanazarovna-TUTOR'S SUPPORT OF FUTURE TEACHERS. European Journal of Research and Reflection in Educational Sciences Vol. 8 No. 3, 2020 Part II ISSN 2056-5852

5. Бекимбетова Айнагул Амангельдиевна-ПРОФЕССИОНАЛЬНОЕ САМОСОВЕРШЕНСТВОВАНИЯ ПЕДАГОГОВ В ОБРАЗОВАТЕЛЬНОМ ПРОСТРАНСТВЕ. Теория и практика современной науки No9(51), сентябрь, 2019

6. The Way of Science International scientific journal № 4 (74), 2020 Founder and publisher: Publishing House «Scientific survey» The journal is founded in 2014 (March)

7. Международном научно-практическом журнале «Теория и практика современной науки» Бекимбетона А. А., Сапаров А. Т. ВОПРОСЫ УСПЕШНОЙ ОРГАНИЗАЦИИ ДЕЯТЕЛЬНОСТИ ВОСПИТАТЕЛЕЙ

\footnotetext{
${ }^{4}$ Международном научно-практическом журнале «Теория и практика современной науки» Бекимбетона А. А., Сапаров А. Т. ВОПРОСЫ УСПЕШНОЙ ОРГАНИЗАЦИИ ДЕЯТЕЛЬНОСТИ ВОСПИТАТЕЛЕЙ
} 